\title{
PENGEMBANGAN KETERAMPILAN SOSIAL UNTUK MEMBENTUK PRILAKU SOSIAL ANAK USIA DINI
}

\author{
Tuti Istianti ${ }^{1}$
}

\begin{abstract}
ABSTRAK
Masa usia PAUD adalah masa keemasan (golden age) saatnya memperoleh stimulasi seluruh aspek perkembangan termasuk aspek sosial-emosinya. Masamasa kehidupan awal anak, merupakan fase terpenting pertumbuhan otak dan mengalami perkembangan yang sangat pesat. Pendidikan anak usia dini ini diberikan agar dapat berkembang secara optimal. Mengingat pentingnya masa usia ini, peran stimulasi berupa penyediaan lingkungan yang kondusif yang disiapkan pendidik baik akan sarana prasarana, penanganan pengasuhannya sehingga anak memiliki kesempatan untuk mengembangkan seluruh potensinya, diantaranya nilainilai agama, emosi, sosial, dan kemandiriannya.

Upaya untuk mengembangkan keterampilan sosial harus dilakukan melalui kegiatan bermain. Dengan bermain anak memperoleh kesempatan yang sangat luas untuk berkreasi, bereksplorasi, menemukan, dan mengekspresikan perasaannya. Kegiatan pembelajarannya perlu memberikan dorongan kepada anak untuk mengungkapkan kemampuan dalam membangun gagasan, bekerjasama, berinteraksi, bertanggung jawab. Suasana pembelajaran yang dirancang melalui mengembangkan keterampilan sosial akan mendorong dan menciptakan anak untuk meningkatkan kemampuan berpikir, berprilaku berdasarkan keragaman realitas sosial.
\end{abstract}

\section{Kata Kunci: Pengembangan Keterampilan Sosial, Prilaku Sosial , Anak Usia Dini}

\section{A. PENDAHULUAN}

Menurut para pandangan para ahli, usia dini merupakan masa emas (golden ages) berdasar kajian neuro-science, psikologi, maupun pedagogi masa usia ini sedang mengalami perkembangan yang sangat pesat. Anak sejak dilahirkan telah memiliki 100 milyar sel otak yang saling berhubungan. Sambungan antar sel otak banyak dipengaruhi asupan gizi anak, faktor kesehatan, stimulasi/rangsangan yang diterima dari lingkungan. Terkait dengan perkembangan kecerdasan anak usia dini baik fisik motorik, kognitif bahasa dan perkembangan sosialnya dipengaruhi oleh kesiapan penyelenggaraan dan fasilitas yang mendukungnya termasuk bentuk layanan anak. Semakin baik pelayanan yang diterima anak dari lingkungan tempat belajarnya, anak secara intelegensi, sosial, emosi, menjadi lebih matang sehingga anak mempersiapkan diri untuk mengikuti pendidikan yang lebih lanjut. Pendidikan diberikan sejak usia dini dengan sebaik-baiknya memberi kontribusi

\footnotetext{
${ }^{1}$ Dosen UPI Kampus Cibiru
} 
yang sangat tinggi terhadap kualitas SDM dimasa yang akan datang, bahkan penyiapan SDM unggul seyogianya ditempuh sejak anak masih dalam kandungan.

Sehubungan tujuan pendidikan anak usia dini kaitannya dengan aspek prilaku, sementara ini banyak kasus anak yang mengalami gangguan perilaku. Jenis kasus yang berkembang di Indonesia adalah bunuh diri yang dilakukan anak-anak. Data yang dilansir oleh Komnas Anak, tahun 2014 terdapat kasus bunuh diri anakanak. Sembilan anak itu usia rentan 5 sampai 10 tahun. Sementara 12 hingga 15 tahun ada 39 kasus. Pada Usia 15 tahun ada 27 kasus. (Data Komnas Anak: 2015). Kasus amoral lainnya yang marak terjadi akhir-akhir ini kasus kekerasan antaranak, anak dengan mudah melakukan tindak kekerasan. Contoh kasus di atas anak cenderung imitasi, menirukan apa yang dilihat dan dicontohkan lingkungannya sehingga pelaku bisa juga melakukan pembunuhan. Anak dengan masalah perilaku yang menyimpang kelak menjadi dewasa yang antisosial, setelah dewasa cenderung terlibat dengan tindakan kriminal

Munculnya beberapa kasus di atas anak merupakan indikasi dari kegagalan tercapainya tujuan pendidikan. Beranjak dari fenomena di atas, hubungan yang kuat antara penanaman perilaku sosial dan keterampilan sosial dengan lembaga pendidikan sejak dini perlu dilakukan bersama. Penanaman perilaku sosial pada anak-anak dapat dimulai melalui kurikulum di lembaga pendidikan usia dini. Peran pendidik sangat besar pengaruhnya dalam mengstimulus perilaku anak.

Pendidikan anak usia dini (PAUD) merupakan investasi yang amat besar bagi keluarga dan bagi bangsa. Anak-anak kita adalah generasi penerus keluarga dan sekaligus penerus bangsa. Pengembangan nilai-nilai dan keterampilan sosial harus menjadi salah satu tujuan pendidikan khususnya di PAUD. Sementara ini para pendidik ada kecenderungan mengabaikan pembinaan nilai-nilai sosial dalam pendidikan khususnya pada muatan pembelajaran, mengakibatkan erosi keterampilan sosial. Pendidikan di PAUD berkontribusi terhadap tanggung jawab sosial anak untuk menumbuhkan kepedulian, kesetiaan, toleransi, empati, disiplin, tanggung jawab.

Keterampilan sosial dapat dikembangkan di PAUD agar anak diberi bekal dalam rangka menjalin hubungan yang seimbang dengan sebayanya. Hubungan pertemanan yang seimbang dapat diperoleh jika anak memiliki rasa percaya diri dan bisa menghadapi berbagai masalah serta mencari solusinya.Tujuan pengembangan keterampilan sosial di PAUD dimaksudkan agar anak memiliki keterampilan berinteraksi dengan teman-temannya sehingga hubungan sosialnya lebih baik lagi. Keterampilan sosial dikembangkan di PAUD mempunyai fungsi sebagai sarana untuk memperoleh hubungan yang baik dalam berinteraksi dengan orang lain. Semakin sering anak bergaul dan mempunyai banyak pengalaman langsung dengan banyak situasi sosial maka keterampilan sosial akan membantu pada perkembangan kognitif anak.

Sedangkan nilai-nilai sosial yang diterapkan pada anak usia dini sebagai acuan bertingkah laku terhadap sesamanya, sehingga dapat diterima di masyarakat.

\section{B. PEMBAHASAN}

1. Pengertian Keterampilan Sosial 
Keterampilan sosial merupakan bentuk prilaku, perbuatan, sikap yang ditampilkan oleh individu ketika berinteraksi dengan orang laing baik secara verbal maupun non verbal. Libet dan Lewinsohn (Cartledge dan Milburn, 1995) mengemukakan keterampilan sosial sebagai kemampuan yang kompleks untuk menunjukkan perilaku yang baik dinilai secara positif atau negative oleh lingkungan, dan jika perilaku itu tidak baik akan diberikan punishment oleh lingkungan. Michelson, dkk. (dalam Ramdhani, 1994) menyebutkan bahwa ketrampilan sosial merupakan suatu ketrampilan yang diperoleh individu melalui proses belajar, mengenai cara-cara mengatasi atau melakukan hubungan sosial dengan tepat dan baik.

Secara umum, keterampilan sosial ini dapat dilihat dalam beberapa bentuk perilaku: pertama, perilaku yang berhubungan dengan diri sendiri (bersifat intrapersonal) seperti mengontrol emosi, menyelesaikan permasalahan sosial secara tepat, memproses informasi dan memahami perasaan orang lain; kedua, perilaku yang berhubungan dengan orang lain (bersifat interpersonel) seperti memulai interaksi dan komunikasi dengan orang lain; dan ketiga perilaku yang berhubungan dengan akademis, seperti mematuhi peraturan dan melakukan apa yang diminta oleh guru.

Secara lebih spesifik, Elksnin \& Elksnin (dalam Adiyanti, 1999) mengidentifikasi keterampilan sosial dengan beberapa ciri, yaitu:

\section{1) Perilaku interpersonal}

Merupakan perilaku yang menyangkut ketrampilan yang dipergunakan selama melakukan interaksi sosial. Perilaku ini disebut juga ketrampilan menjalin persahabatan, misalnya memperkenalkan diri, menawarkan bantuan, dan memberikan atau menerima pujian. Ketrampilan ini kemungkinan berhubungan dengan usia dan jenis kelamin.

2) Perilaku yang berhubungan dengan diri sendiri

Merupakan ketrampilan mengatur diri sendiri dalam situasi sosial, misalnya ketrampilan menghadapi stress, memahami perasaan orang lain, mengontrol kemarahan dan sejenisnya. Dengan kemampuan ini, anak dapat memperkirakan kejadian-kejadian yang mungkin akan terjadi dan dampak perilakunya pada situasi sosial tertentu.

3) Perilaku yang berhubungan dengan kesuksesan akademis

Merupakan perilaku atau ketrampilan sosial yang dapat mendukung prestasi belajar di sekolah, misalnya mendengarkan dengan tenang saat guru menerangkan pelajar, mengerjakan pekerjaan sekolah dengan baik, melakukan apa yang diminta oleh guru, dan semua perilaku yang mengikuti aturan kelas.

4) Peer acceptance merupakan perilaku yang berhubungan dengan penerimaan sebaya, misalnya memberi salam, memberi dan meminta informasi, mengajak teman terlibat dalam suatu aktivitas, dan dapat menangkap dengan tepat emosi orang lain.

5) Ketrampilan komunikasi

Ketrampilan komunikasi merupakan salah satu ketrampilan yang diperlukan untuk menjalin hubungan sosial yang baik. Kemampuan anak dalam berkomunikasi dapat dilihat dalam beberapa bentuk, antara lain menjadi pendengar 
yang responsif, mempertahankan perhatian dalam pembicaraan dan memberikan umpan balik terhadap kawan bicara.

\section{Keterampilan Sosial dan Perilaku Sosial pada Anak Usia Dini}

Perilaku sosial merupakan salah satu aspek yang sangat penting untuk dikembangkan karena sangat mempengaruhi proses tumbuh kembang anak. Pengembangan perilaku sosial pada anak usia dini merupakan salah satu aspek yang sangat mendukung perkembangan anak khususnya perkembangan sosial. Orang yang berhasil melakukan perilaku sosial dengan baik apabila mampu melakukan tindakan yang wajar yang sesuai dengan ukuran-ukuran yang digunakan di masyarakat dan diterima. Sebaliknya prilaku sosial yang menyimpang manakala tidak sesuai dengan harapan sebagian besar warga masyarakat. Seseorang yang berhasil melakukan perilaku sosial dengan baik mampu mengembangkan sikap sosial yang menyenangkan, seperti kesediaan untuk membantu orang lain. Belajar berperilaku yang dapat diterima secara sosial terkait dengan standar dari setiap kelompok sosial tentang perilaku yang dapat diterima. Untuk dapat bermasyarakat anak tidak hanya harus mengetahui perilaku yang dapat diterima, tetapi mereka juga harus menyesuaikan perilaku dengan patokan yang dapat diterima.

Bentuk perilaku sosial anak juga dikemukakan oleh Dariyo (2005:114) yaitu "ditandai dengan adanya proses identifikasi." Seorang anak mampu untuk mengembangkan perilaku sosial secara positif yang ditandai dengan kemampuan untuk memiliki hubungan secara emosional, seorang anak akan dapat menyerap nilai-nilai, norma-norma dan etika dari budaya sosialnya terutama dari orangtua dan gurunya. Lingkungan berperan dalam pengembangan moral anak usia dini.

Melalui proses tersebut, sebenarnya seorang anak akan mengimitasi atau meniru sikap dan tindakan tokoh model guna melakukan proses identifikasi dengan orangtuanya. Keberhasilan melakukan proses identifikasi ditandai dengan kesadaran internal bahwa seseorang melakukan tindakan-tindakan yang sesuai dengan nilai, etika atau norma sosial budaya, bukan karena dipaksa atau terpaksa, tetapi karena anak memang sadar apa yang dilakukan tersebut merupakan hal yang benar.

Sementara itu, Buhler (Abin Syamsuddin Makmun, 2003) mengemukakan tahapan dan ciri-ciri perkembangan perilaku sosial individu sebagaimana dapat dilihat dalam tabel berikut :

\begin{tabular}{|c|c|}
\hline Tahap & Ciri-Ciri \\
\hline $\begin{array}{l}\text { Kanak-Kanak Awal }(0-3) \\
\text { Subyektif }\end{array}$ & $\begin{array}{l}\text { Segala sesuatu dilihat berdasarkan } \\
\text { pandangan sendiri }\end{array}$ \\
\hline $\begin{array}{c}\text { Kritis I }(3-4) \\
\text { Trozt Alter }\end{array}$ & Pembantah, keras kepala \\
\hline $\begin{array}{c}\text { Kanak - Kanak Akhir }(4-6) \\
\text { Masa Subyektif Menuju } \\
\text { Masa Obyektif }\end{array}$ & $\begin{array}{l}\text { Mulai bisa menyesuaikan diri dengan } \\
\text { aturan }\end{array}$ \\
\hline $\begin{array}{c}\text { Anak Sekolah }(6-12) \\
\text { Masa Obyektif }\end{array}$ & $\begin{array}{c}\text { Membandingkan dengan aturan - } \\
\text { aturan }\end{array}$ \\
\hline
\end{tabular}




\begin{tabular}{|c|c|}
\hline $\begin{array}{c}\text { Kritis II ( } 12-13) \\
\text { Masa Pre Puber }\end{array}$ & $\begin{array}{c}\text { Perilaku coba-coba, serba salah, ingin } \\
\text { diuji }\end{array}$ \\
\hline $\begin{array}{c}\text { Remaja Awal }(13-16) \\
\text { Masa Subyektif Menuju } \\
\text { Masa Obyektif }\end{array}$ & $\begin{array}{c}\text { Mulai menyadari adanya kenyataan } \\
\text { yang berbeda dengan sudut } \\
\text { pandangnya }\end{array}$ \\
\hline $\begin{array}{c}\text { Remaja Akhir ( } 16-18) \\
\text { Masa Obyektif }\end{array}$ & $\begin{array}{c}\text { Berperilaku sesuai dengan tuntutan } \\
\text { masyarakat dan kemampuan dirinya }\end{array}$ \\
\hline
\end{tabular}

Prilaku sosial anak diperoleh melalui proses pengalaman belajarnya. Pengembangan nilai-nilai dan keterampilan sosial bisa dicapai melalui pendidikan di PAUD. Perkembangan keterampilan sosial anak tergantung pada berbagai faktor, yaitu kondisi anak sendiri serta pengalaman interaksinya, baik dengan orang tua, guru, dan lingkungan belajarnya. Keterampilan sosial penting dikembangkan guru di kelas dan memiliki kontribusi terhadap tanggung jawab sosial anak, seperti rasa memiliki, melatih disiplin, tolong menolong, toleransi melalui pembiasaan. Pembentukan kepribadian anak dapat ditempuh melalui pembelajaran.

Contoh muatan keterampilan sosial yang perlu dimiliki anak usia dini, meliputi: keterampilan bertanya, menjalin dan memelihara pertemanan, bekerjasama, mau berbagi, berinteraksi, kemampuan memecahkan masalah

\section{Metode Pembelajaran yang mendukung Keterampilan Sosial di PAUD}

Ada berbagai metode yang disarankan untuk melatih keterampilan sosial dan kecerdasan sosial anak yaitu melalui pembelajaran kooperatif. Pembelajaran kooperatif pada dasarnya berpusat pada anak dan banyak melatih untuk bekerjasama yang terintegrasi kegiatannya sambil bermain. Aktivitas bermain berperan sangat penting, terutama yang berhubungan dengan Basic Life Skill, seperti keterampilan berkomunikasi, bersosialisasi, bernegosiasi, dan bekerjasama dalam tim, bisa dipelajari dari proses bermain. Suhendi (2001:8) yang menjelaskan bahwa:setiap diri manusia, baik anak-anak maupun orang dewasa terdapat hasrat untuk bermain. Seperti halnya kebutuhan bersosialisasi dan berkelompok, bermain merupakan hasrat yang mendasar pada diri manusia. Anak-anak ingin bermain karena saat itulah mereka mendapatkan berbagai pengalaman lewat bermain melalui eksplorasi alam di sekitarnya. Dimata anak-anak, ada beberapa alasan kenapa permainan dibutuhkan sebagai media pembelajarnya. Menurut Sudono (2006: 20) beberapa alasan tersebut adalah sebagai berikut :

(1) Anak-anak membutuhkan pengalaman yang kaya, bermakna, dan menarik, (2) Otak anak senang pada sesuatu yang baru dan hal hal baru yang menantang dan menarik, (3) Rangsangan otak sensori multimedia penting dalam pembelajaran. Makin banyak yang terlibat (visual, audio, dan audio visual) dalam suatu aktivitas, makin besar pula kemungkinan siswa untuk belajar, (4) Anak umumnya senang bergerak, jadi jangan lupa memasukan gerak dalam pembelajaran, (5) Pengulangan adalah kunci belajar. Berikan kegiatan yang membuat siswa dapat mengulang pembelajaran tanpa rasa bosan dan jenuh, (6) Permainan (games) menyenangkan bagi anak. 
Keinginan untuk belajar dapat meningkat dengan adanya tantangan dan terhabat oleh ancaman yang disertai oleh rasa tidak mampu atau kelelahan.

Berikut dipaparkan beberapa contoh keterampilan sosial yang dapat dikembangkan guru di PAUD:

a. Untuk melatih anak agar memiliki kesadaran akan dirinya sendiri (awareness) pada tujuan kenal diri, kegiatan yang bisa dilakukan guru untuk mengenali identitas diri anak dengan cara bertanya : siapa namanya, siapa nama orangtuanya, di mana tempat tinggalnya, apakah jenis kelaminnya, lelaki atau perempuan, apa kesukaannya, cita-cita, maupun perilaku dirinya seperti apa dalam menghadapi lingkungan.

b. Kegiatan yang melatih rasa empati anak atau melatih kepedulian dan kepekaan anak, dengan cara mengajak anak untuk merasakan dan membayangkan jika ada orang lain mengalami musibah, guru bercakap-cakap bertanya tentang bagaimana perasaan anak jika musibah itu dialami oleh kita sendiri.

c. Keterampilan untuk melatih rasa simpati anak, guru bisa bercerita atau melihat langsung penderitaan orang lain dengan segala kekurangannya, anak diajak bersama-sama memikirkan apa yang dilakukan dengan kondisi tersebut dan perbuatan apa yang harus dilakukan anak. Anak belajar terlibat dengan perasaan dan emosinya dan tindakan yang pantas dilakukan anak.

d. Keterampilan sosial ini mengajarkan pada anak untuk mau berbagi, ajari anak untuk berbagi makanan, berbagi mainan dengan cara bergiliran memainkannya.

e. Keterampilan bernegosiasi, guru membiasakan anak untuk belajar mengungkapkan pendapat, keinginannya, membiasakan anak berlatih menyelesaikan masalah yang dihadapi, dan bagaimana bersikap pada saat menghadapi berbagai situasi sosial. Mengajarkan anak tidak menangis jika diejek teman, beri kesempatan pada anak untuk mengungkapkan perasaan yang diterimanya dari perlakuan temannya, mengutarakan harapan dari temannya. Latihan negosiasi di PAUD dengan tujuan selain akan menumbuhkan rasa percaya diri anak juga belajar untuk menghindari dan berlatih menyelesaikan konflik.

Contoh-contoh melatih keterampilan sosial tersebut guru bisa melakukan kegiatannya melalui bermain peran, metode proyek, dan kerja kelompok.

\section{PENUTUP}

Keterampilan sosial dapat dikembangkan di PAUD guna membantu anak didik menumbuhkan dan memperkuat sistem nilai yang dimilikinya sebagai dasar untuk berperilaku dalam kehidupan sehari-hari. Keterampilan sosial menekankan pada pengembangan kemampuan sikap yang baik, konsisten dengan perbuatan berdasarkan kepada sistem nilai yang berlaku di tengah-tengah masyarakat. Keterampilan sosial dapat dikembangkan guru dipadukan dengan metode bermain peran menggunakan strategi yang tepat dan sesuai dengan karakteristik perkembangan anak. 


\section{DAFTAR PUSTAKA}

Abin Syamsuddin Makmun. 2003. Psikologi Pendidikan. Bandung : PT Rosda Karya Remaja

Cartledge, G. \& Milburn, J. F. (1995). Teaching social skills to children \&youth Innovative Approaches(3rded.). Massachussetts : Allyn and Bacon.

Sudono, Anggani (2006) Sumber Belajar dan Alat permainan untuk Anak Usia Dini, Jakarta: Grasindo

Suhendi, A., dkk (2001) Mainan da n Permainan. Nakita. Juni 2001. Jakarta: PT. Gramedia 